\title{
Further physicochemical characterization of anchomanes difformis starch
}

\section{Afolayan, Michael $0^{1^{*}}$, Omojola, Moses O. $^{2}$, Onwualu A. P.. ${ }^{1}$, Thomas, Sunday A. ${ }^{1}$}

\author{
${ }^{1}$ Sheda Science and Technology Complex, PMB 186 Garki, Abuja, Nigeria \\ ${ }^{2}$ Raw Materials Research and Development Council, PMB 232 Garki, Abuja, Nigeria \\ corresponding author's email (afolayanmic@yahoo.com)
}

\section{ABSTRACT}

\begin{abstract}
Anchomanes difformis (Blume) Engl. [family ARACEAE] is an herbaceous plant with prickly stem having huge divided leaf and spathe that arise from a horizontal tuber occurring in the forest of West Africa and presently untilized. The tuber of the plant was examined for its starch composition and physicochemical properties. The starch was isolated using $1 \% \mathrm{w} / \mathrm{v}$ sodium metabisulphite and it gave a yield of about $21 \%$ which is slightly off white in colour. The starch percentage solubility at $85{ }^{\circ} \mathrm{C}$ was 17.32 with a swelling power of 9.66 and gelatinization temperature of $72{ }^{\circ} \mathrm{C}$. It has a browning temperature of $257.0-268.2^{\circ} \mathrm{C}$, charring temperature of $281.4-291.6^{\circ} \mathrm{C}$, water absorption capacity of $71 \%$, pH of 5.6 , foam and emulsion capacities of $3.6 \%$ and $9.17 \%$ respectively. Phytochemical screening of the starch revealed the presence of carbohydrates, terpenoids, saponins and cardiac glycosides while the proximate analysis (in $\%$ ) was found to be: fat -1.0 , ash -0.75 , crude fibre -1.6 , protein -0.66 , moisture -6.0 , and carbohydrates - 88.9.The paste clarity was determined at $580 \mathrm{~nm}$ as a function of the starch concentration. The photomicrograph indicates that the starch granule is generally small sized, not distinct but clustered with size ranging between $1-1.5 \mu \mathrm{m}$ which is a reflection of the parent source. Generally, the values obtained from the physicochemical characterization of anchomanes difformis starch show that it has high potential for industrial applications especially in the food, textile and pharmaceutical industries.
\end{abstract}

Keywords: Anchomanes difformis, physicochemical properties, starch, phytochemical screening, paste clarity

\section{INTRODUCTION}

Starch is one of the most abundant organic chemicals on earth. It is found in the leaves of green plants in the plastids where it is synthesized. It is also synthesized in the amyloplasts of seeds, grains, roots and tubers of most plants where it serves as the chemical storage form of energy (Jay-lin et al., 1994). Some lesser known and unconventional crops could be good sources of nutrients and starch and even have the potential of broadening the present narrow food base of the human species (Viano et al., 1995) but the lack of data on the chemical composition and properties of such plants has limited the prospects for their utilization (Vijayakumari et al., 1994). In most developing tropical countries, the food situation is worsening owing to increasing population, shortage of fertile land which ultimately results in high prices of available staple foods (Sadik, 1991). This has resulted in a high incidence of hunger and malnutrition, a situation in which children and women, especially pregnant and lactating women are most vulnerable. (Weaver, 1994).
Starch is also one of the most widely used biomaterial in the food, textile, cosmetics, plastics, adhesives, paper and pharmaceutical industries. The diverse industrial usage of starch is based on its availablity at low cost, high calorific value and inherent excellent physicochemical properties (Omojola et al., 2010). The versatility of starch in industrial applications is clearly defined by its physicochemical properties; therefore, a thorough evaluation of the necessary parameters is important in elucidating its industrial use. The morphology and physicochemical characteristics of starch are typical of its biological origin hence, starch from each plant source will vary somewhat in appearance, composition and properties (Gebre - Mariam et al., 2006). As a result of the competing demands for starch as food, pharmaceutical and industrial uses coupled with the need to attain self sufficiency in starch production, there is a need to find other high yield sources different from cassava, maize and potato. 
Starch extracted from various locally available tubers, rhizomes and fruits have been studied by many researchers and find application in several industries. Little work appears to have been done on the isolation and physicochemical characterization of starch from anchomanes difformis. Anchomanes difformis is a specie of flowering plants in the family Araceae. It is an herbaceous plant with prickly stem having huge divided leaf and spathe that arise from a horizontal tuber growing as a wild yam in the forest of West Africa.

The purpose of this study is to extract, characterise and provide more data on the various physicochemical characterization of anchomanes difformis starch as a new starch source for industrial use which can reduce the burden on other starch sources such as cassava, corn, yam, potatoes and other complex carbohydrates.

\section{MATERIALS AND METHODS:}

Materials: Anchomanes difformis tubers were harvested fresh from the farm source in lyere Owo, Ondo state, South - West Nigeria. Corn starch (BP) and other analytical grade reagents were obtained from Chemistry Advanced Laboratory, Sheda Science and Technology Complex, Abuja Nigeria.

Starch Isolation: The fresh tubers were peeled and washed. Peeled tubers $(3 \mathrm{~kg})$ were chopped into small pieces and soaked in sodium metabisulphite solution $(2 \mathrm{~L} 1 \% \mathrm{w} / \mathrm{v})$ at room temperature $\left(28^{\circ} \mathrm{C}\right)$. Thereafter, the pieces of tuber were removed and wet milled into a slurry using a grater. The paste was dispersed in a large volume of $1 \%$ sodium metabisulphite and filtered through muslin cloth. The suspension did not settle even when kept over night and so it was centrifuged at $3500 \mathrm{rpm}$ for $10 \mathrm{~min}$, the supernatant was carefully decanted and the mucillage scraped off. The process was repeated for three times with the mucilage on the starch scraped continously until a pure starch was obtained. The resulting starch was dried in the sun and further dried at $60{ }^{\circ} \mathrm{C}$ in a hot air oven, pulverized, weighed and stored in sample bottles for analysis.

\section{Determination of certain physicochemical properties:}

Swelling power: The method described by Daramola et al (2006) was used to determine the swelling power with slight variations. The starch sample $(0.1 \mathrm{~g})$ was weighed into a test tube and 10 $\mathrm{ml}$ of distilled water was added. The mixture was heated in a water bath at a temperature of $50{ }^{\circ} \mathrm{C}$ for
30 min with continuous shaking. In the end, the test tube was centrifuged at $1500 \mathrm{rpm}$ for $20 \mathrm{~min}$ in order to facilitate the removal of the supernatant which was carefully decanted and weight of the starch paste taken. The swelling power was calculated as follows:

$$
\text { Swelling power }=\frac{\text { Weight of starch paste }}{\text { Weight of dry starch sample }}
$$

This was carried out over a temperature range of 50 ${ }^{\circ} \mathrm{C}-100{ }^{\circ} \mathrm{C}$.

Solubility Index: Solubility index was determined over a temperature range of $50{ }^{\circ} \mathrm{C}-100{ }^{\circ} \mathrm{C}$ as follows: Starch sample $(0.5 \mathrm{~g})$ was added to $10 \mathrm{ml}$ distilled water in a test tube. This was subjected to heating in a water bath with a starting temperature of $50{ }^{\circ} \mathrm{C}$ for $30 \mathrm{~min}$. It was then centrifuged at $1500 \mathrm{rpm}$ for $30 \mathrm{~min} .5 \mathrm{ml}$ of the supernatant was decanted and dried to constant weight. The solubility was expressed as the percentage (\%) by weight of dissolved starch from heated solution.

Gelatinization temperature: This was evaluated using the method of Attama et al (2003). The starch sample $(1 \mathrm{~g})$ was put in a $20 \mathrm{ml}$ beaker and $10 \mathrm{ml}$ of distilled water was added. The dispersion was heated on a hot plate. The gelatinization temperature was then read with a thermometer suspended in the starch slurry.

Water holding capacity: The method of Omojola et al (2010) was used with slight modifications. The starch sample $(5 \% \mathrm{w} / \mathrm{v})$ was dispersed in a preweighed centrifuge tube. The tube was agitated in a vortex mixer for $2 \mathrm{~min}$. The supernatant was then discarded and the weight of the tube and hydrated sample taken. The weight was calculated and expressed as the weight of water bound by $100 \mathrm{~g}$ dry starch.

Amylose content: Amylose content determination was carried out using a colorimetric iodine affinity procedure. The starch sample $(0.1 \mathrm{~g})$ standard was weighted into a test tube. To the test tube was added carefully $1 \mathrm{ml}$ of $95 \%$ ethanol and $9 \mathrm{ml} 1 \mathrm{~mol} / \mathrm{dm}^{3}$ $\mathrm{NaOH}$. The tube was covered with foil, thoroughly mixed and heated for 10 min in boiling water both to gelatinize the starch, thereafter it was cooled very well. The suspension was diluted 10 times. An aliquot of $0.5 \mathrm{ml}$ of the extract was used for analysis where $0.1 \mathrm{ml}$ of acetic acid solution was added, followed by the addition of $0.2 \mathrm{ml}$ of iodine solution. This was made up to $10 \mathrm{ml}$ mark with distilled water. The solution was left for 20 min for colour development, and absorbance was read at $620 \mathrm{~nm}$. 
Foam capacity: The method of Omojola et al (2010) was used with slight modifications. Starch sample (1 g) was homogenized in $50 \mathrm{ml}$ distilled water using a vortex mixer (vortex 2 Genie set at shake 8) for 5 minutes. The homogenate was poured into a $100 \mathrm{ml}$ measuring cylinder and the volume recorded after 30 s. The foam capacity was expressed as the percent increase in volume.

Emulsion capacity: The method of Omojola et al (2010) was again used also with slight modifications. Sample $(1 \mathrm{~g})$ was dispersed in $5 \mathrm{ml}$ distilled water using a vortex mixer for 30 seconds. After complete dispersion, $5 \mathrm{ml}$ vegetable oil (groundnut oil) was added gradually and the mixing continued for another $30 \mathrm{~s}$. The suspension was centrifuged at $1600 \mathrm{rpm}$ for $5 \mathrm{~min}$. The volume of oil separated from the sample was read directly from the tube. Emulsion capacity is the amount of oil emulsified and held per gram of sample.

Browning and charring temperature: The method of Builders et al (2001) was used. Some of the starch sample was put into a capillary tube, the browning and charring temperatures were determined using a melting point apparatus with model Electrothermal 9100.

Proximate analysis: Moisture, protein, fat, ash, crude fibre and carbohydrates was determined according to AOAC (1990).

pH: A $20 \% \mathrm{w} / \mathrm{v}$ dispersion of the sample was shaken in water for 5 minutes and the $\mathrm{pH}$ was determined using a $\mathrm{pH}$ meter.

All the above parameters were determined in triplicates and the mean and standard deviations were recorded.

Paste clarity: This was determined spectrophotometrically. Accurate concentrations of the starch slurry between $0.15-2.5 \% \mathrm{w} / \mathrm{v}$ were made in different boiling tubes and heated in a water bath for 30 minutes. The transmittance was determined at $580 \mathrm{~nm}$ using a UV spectrophotometer with cassava starch as the reference standard (Builders et al, 2001).

Scanning electron microscopy: A scanning electron microscope (SEM) model EVO/ MA 10 was used to determine the particle size at $500 \mathrm{X}, 1 \mathrm{KX}$ and $2 \mathrm{KX}$ magnifications. The sample was imaged with the secondary electron detector at an accelerating voltage of $20 \mathrm{kV}$, probe current of $200 \mathrm{PA}$ and variable pressure of $50 \mathrm{~Pa}$.
Differential scanning calorimetry: Gelatinization properties of the sample was characterized using a Netzsch DSC 204 FI Phoenix (Netzsch, Germany). Nitrogen at the rate of $20 \mathrm{ml} / \mathrm{min}$ was used as purge gas; $2.7 \mathrm{mg}$ of powdered material was sealed in an aluminium pan and heated from $30^{\circ} \mathrm{C}$ up to $400{ }^{\circ} \mathrm{C}$ at the rate of $10^{\circ} \mathrm{C} / \mathrm{min}$, followed by a cooling cycle back to $30{ }^{\circ} \mathrm{C}$ at the same rate. The onset gelatinization temperature $\left(T_{o}\right)$, peak temperature $\left(T_{p}\right)$ and gelatinization temperature at end $\left(T_{e}\right)$ were recorded.

Phytochemical screening: Preliminary phytochemical screening of the starch extracted was done according to the proceedures described by Sofowora (1993). Cardiac glycosides screening was done using the Liberman's test. In this method, a small quantity of the extract was dissolved in $2 \mathrm{ml}$ of acetic anhydride and cooled well in ice. Concentrated sulphuric acid was then carefully added. A violet colour which changes to blue and then to green indicates the presence of a steroidal nucleus.

\section{RESULTS}

Table 1 shows some physicochemical properties of the starch. The photomicrographs of the sample at various magnifications are depicted in Plate 1, the DSC spectra is shown in Fig. 1 while the swelling and solubility patterns for the sample are given in Fig. 2 and 3. The paste clarity is shown in Fig. 4.

The phytochemical screening of the starch shows that it contains terpenoids, saponins, carbohydrates and cardiac glycosides.

Table 1: Physicochemical properties of Anchomanes difformis starch

\begin{tabular}{|l|l|}
\hline PARAMETERS & VALUE \\
\hline $\mathrm{pH}$ & $5.6 \pm 0.0$ \\
\hline Fat $(\%)$ & $1.0 \pm 0.1$ \\
\hline Moisture content (\%) & $6.0 \pm 0.1$ \\
\hline Protein (\%) & $0.66 \pm 0.01$ \\
\hline Ash (\%) & $0.75 \pm 0.01$ \\
\hline Carbohydrate (\%) & $88.9 \pm 0.2$ \\
\hline Crude fibre (\%) & $1.6 \pm 0.2$ \\
\hline Water absorption capacity (ml) & $71.0 \pm 0.1$ \\
\hline Amylose content (\%) & $10.42 \pm 0.02$ \\
\hline Foam capacity $(\%)$ & $3.6 \pm 0.3$ \\
\hline Emulsion capacity $(\%)$ & $9.2 \pm 0.1$ \\
\hline Gelatinization temperature $\left({ }^{\circ} \mathrm{C}\right)$ & $72 \pm 0.0$ \\
\hline Browning temperature $\left({ }^{\circ} \mathrm{C}\right)$ & $257.0-268.2 \pm 0.0$ \\
\hline Charring temperature $\left({ }^{\circ} \mathrm{C}\right)$ & $281.4-291.6 \pm 0.0$ \\
\hline
\end{tabular}


Agric. Biol. J. N. Am., 2012, 3(1): 31-38

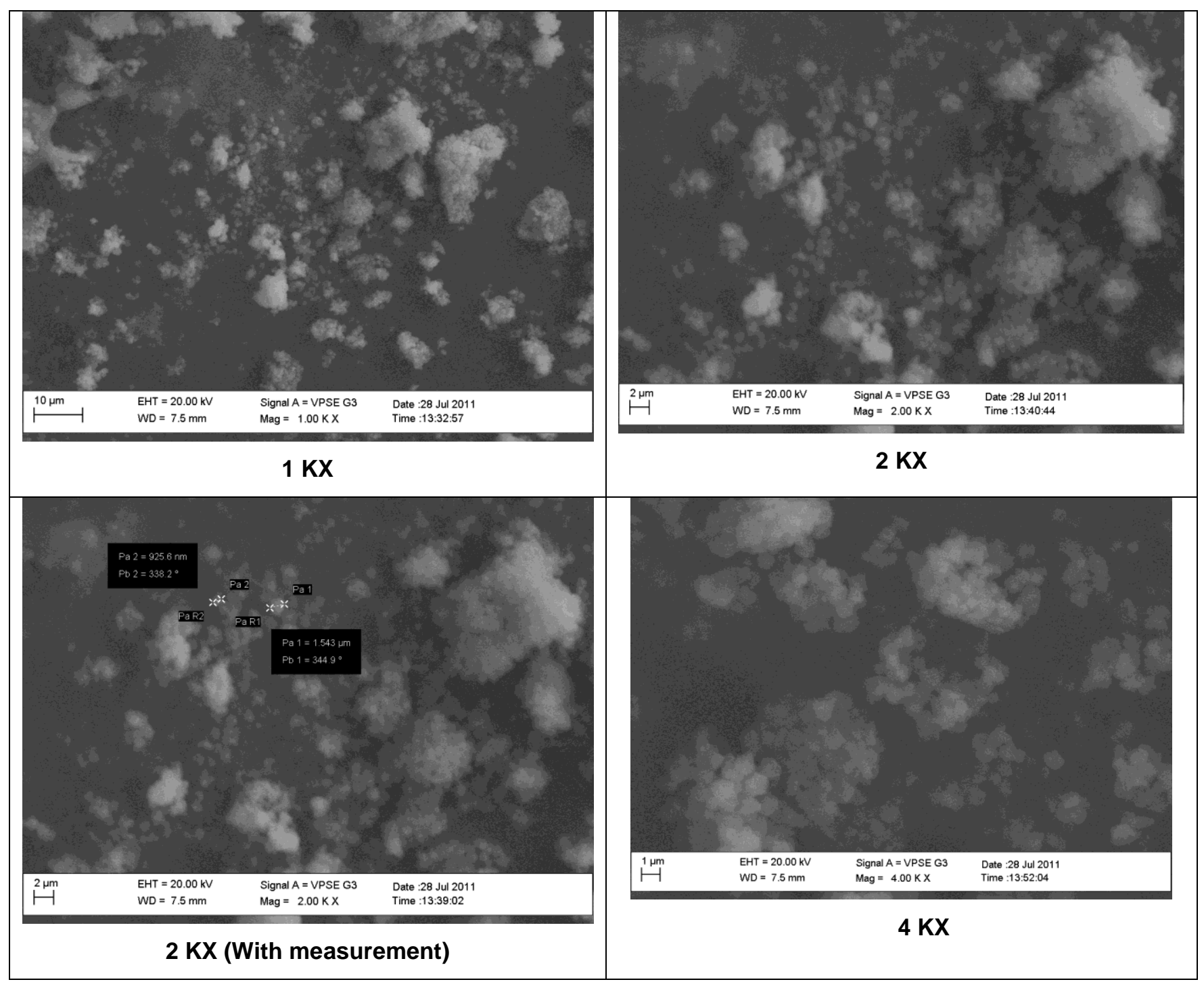

Plate 1: Photomicrograph of anchomanes starch sample at $1 \mathrm{KX}, 2 \mathrm{KX}$ and $4 \mathrm{KX}$ respectively 


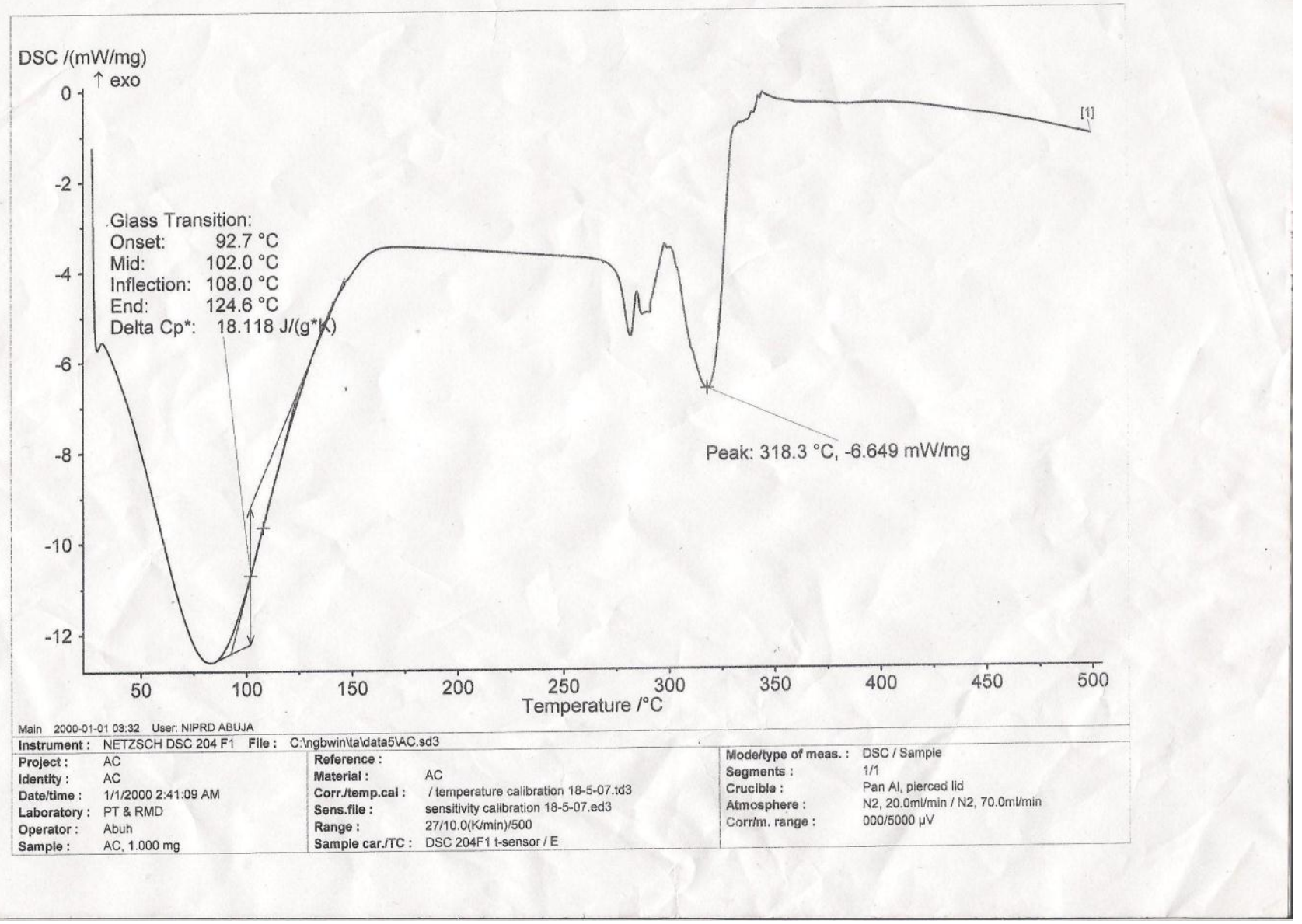

Fig 1: DSC thermogram of anchomanes difformis starch

Table 2: DSC thermograms of Anchomanes difformis starch

\begin{tabular}{|l|l|}
\hline PARAMETERS & VALUE \\
\hline Gelatinization temp. $\left({ }^{\circ} \mathrm{C}\right)$ & 72 \\
\hline Pasting temp. $\left({ }^{\circ} \mathrm{C}\right)$ & 78 \\
\hline Onset temp. $\mathrm{T}_{\mathrm{o}}\left({ }^{\circ} \mathrm{C}\right)$ & 92.7 \\
\hline Peak temp. $\mathrm{T}_{\mathrm{p}}\left({ }^{\circ} \mathrm{C}\right)$ & 318.3 \\
\hline Endset temp. $\mathrm{T}_{\mathrm{e}}\left({ }^{\circ} \mathrm{C}\right)$ & 124.6 \\
\hline$\triangle^{\mathrm{T}}\left(\mathrm{T}_{\mathrm{e}}-\mathrm{T}_{\mathrm{o}}\right)$ & 31.9 \\
\hline
\end{tabular}

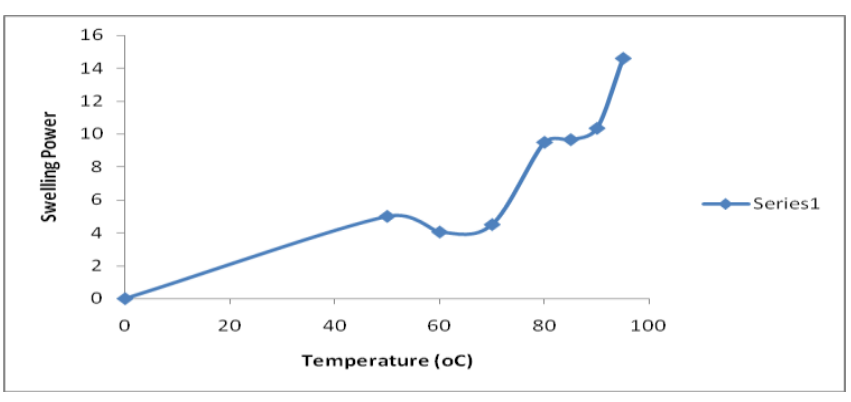

Fig 2: Swelling profile for anchomanes difformis starch 


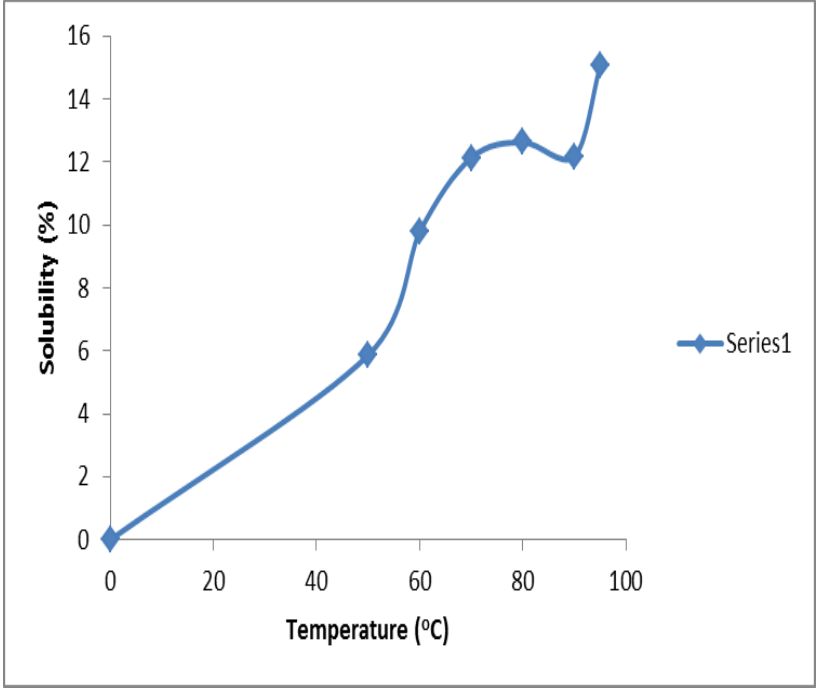

Fig 3: Solubility profile for anchomanes difformis starch

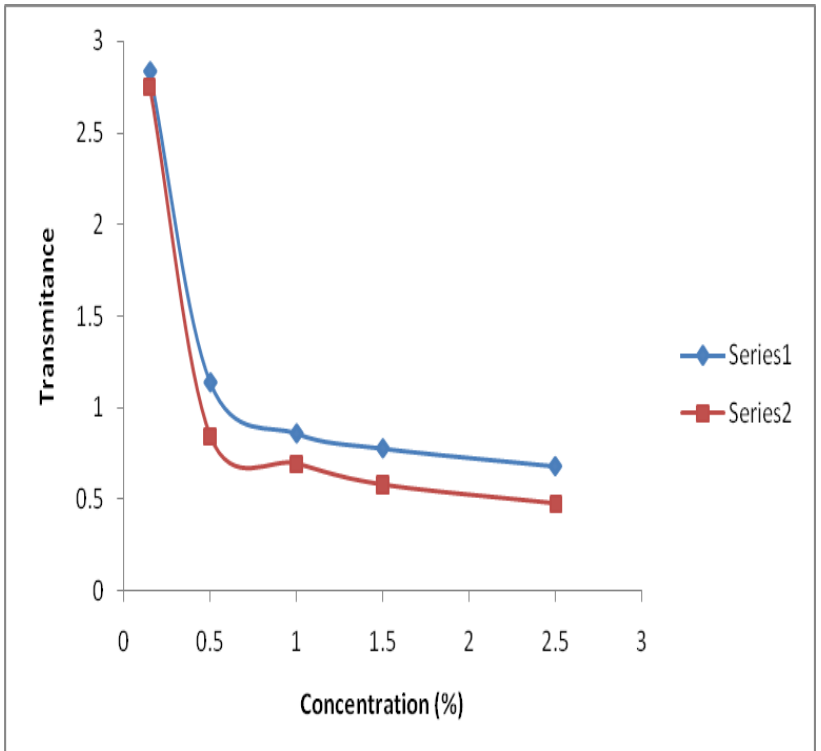

Fig 4: Paste clarity for anchomanes and cassava starch

\section{DISCUSSION}

Chemical Composition: Anchomanes starch was isolated from freshly harvested tubers of anchomanes difformis. The starch obtained was slightly off white in colour with no smell and a yield of about $21 \%$. The yield is considered to be appreciable especially when compared with starches from other sources such as cassava and corn. The $\mathrm{pH}$ measurement shows that anchomanes starch is very close to that of corn starch (Omojola et al, 2010), comparable with the previous $\mathrm{pH}$ values reported for tuber starches (Coursey and Rasper, 1967) and within the $\mathrm{pH}$ range of $3-9$ obtained for most starches used in the pharmaceutical, cosmetics and food industries. Proximate analysis of the starch sample shows that its contents are comparable with that of cassava starch and within the range earlier reported (Adejumo et al, 2011). The low amounts of proteins, lipids and fibre are typical of tuber and root starches (Charles et al, 2004). The foam and emulsion capacities are generally low which is a reflection of the low fat content and an indication that it cannot be used as an emulsifier. The browning and charring temperatures indicates the temperature to which starch can be heated without changing colour or charring. This is observed to be quite high for anchomanes starch and quite higher than the reported value for some other starches (Builders et al, 2001). This shows that the starch can even be heated to a higher temperature without changing colour or charring. This quality will make it a preferable starch in industries that use starch at higher temperatures. The starch was also observed to have a very low amylose content which makes it a good choice food for diabetics and other health conscious individuals (Agbo et al, 2010).

Swelling and Solubility: The swelling and solubility profiles of anchomanes starch over a temperature range of $50-100{ }^{\circ} \mathrm{C}$ are shown in Fig. 2 and 3 . The profiles show a general trend of increase with increase in temperature although a slightly two stage swelling pattern can be observed for the starch. This is an indication of the water absorption characteristic of the granules during heating. There is first, a slight decrease from $50-60{ }^{\circ} \mathrm{C}$ followed an increase up till $80^{\circ} \mathrm{C}$ then a slight level off and then another rapid increase from $90{ }^{\circ} \mathrm{C}$. This pattern has been attributed to two sets of internal bonding forces that relax at different temperatures (Loss et al, 1981). The solubility profile also shows an increase in solubility with temperature rise which relaxes at 90 ${ }^{\circ} \mathrm{C}$ before rising again. The swelling power is slightly lower than that of cassava starch but higher than that of corn starch. Increase in swelling power is indicative of suitablity of a starch being used as a disintegrant in the pharmaceutical industry (Chowdary et al, 2011) hence anchomanes starch can be used as a disintegrant in the formulation of tablets. Also high swelling power results into high digestibility and ability to use starch in solution suggesting improved dietary properties and the use 
Agric. Biol. J. N. Am., 2012, 3(1): 31-38

of starch in a range of dietary applications (Nuwamanya et al, 2010) ), this confirms the applicability of anchomanes starch in other industries.

Morphology: Plate 1 shows the photomicrograph of anchomanes starch at various magnifications using a scanning electron microscope. The starch granules are very small sized, haxagonal in shape and show aggregation forming lumps which is the reason why the starch suspension does not settle even when left over night. It has a particle size that ranges between $1-1.5 \mu \mathrm{m}$. This is much lower than the granule size of $4-4.5 \mu \mathrm{m}$ reported by Ajayi et al (1996) for anchomanes starch; this is due to the fact that a light microscope was used then as against the present work that employed a scanning electron microscope. The granule size is comparable to that of amaranth starch (Bandhari and Singhal, 2002) and such small sized starches are more reactive than starches with larger granule size (Trubiano, 1987). Generally, small and medium sized starch granules have been reported to have varied utilization in the food and pharmaceutical industries(Omojola et al, 2010) which gives credence to the industrial potentials of the starch.

Gelatinization Properties: The Differential Scanning Calorimetry provides an accurate and reproducible method for monitoring the gelatinization process for starches. This is the process whereby starches undergo an irreversible change under heat and absorb water with swelling thereby making the granules swell more and become a paste rather than a dispersion which it forms in cold water. The starch sample was observed to have a gelatinization temperature of $72{ }^{\circ} \mathrm{C}$ which falls within the range of gelatinization temperatures commonly observed for starches although, an earlier work (Ajayi et al, 1996) reported a range of $52-64{ }^{\circ} \mathrm{C}$. The slight variation in the value obtained may be due to the location of raw material source and the period of harvest.

The DSC thermogram for anchomanes starch is shown in Fig. 1 while the values are recorded in Table 2.

CONCLUSION: Some physicochemical properties of anchomanes difformis starch have been examined and these properties compare favourably with other starches. The study has therefore shown that anchomanes difformis is a good source of starch and is therefore a potential source of industrial starch. This will help to reduce the burden on starch from other well known sources such as corn, potato and cassava and make starch available at low cost.

\section{REFERENCES:}

Adejumo A. L., Aderibigbe A. F., Layokun S. K., (2011): Cassava starch: production, physicochemical properties and hydrolysation - a review; Advances in Food and Energy Security 2: 8-17

Agbo I. U., and Odo G. E. (2010): The effect of hypochlorite oxidation and acetylation on some of the physicochemical properties of icacina trichantha starch; Bio - Research 8 (1): 593 - 597

Ajayi G. O., Kabele - Toge B. B., Wodi M. O. And Williams A. O. (1996): Physico - chemical properties of starch obtained from two Nigerian plants Ipomoea batatas and Anchomanes difformis; West Afr. J. Biol. Sci., 5 (1) $77-83$

AOAC (1990). Official methods of Analysis. $15^{\text {th }} \mathrm{Ed}$, Association of official analytical chemists. Washington D.C, pp: 808,831-835.

Attama A. A., Nnamani P. O., Mbonu I. K. and Adiku M. U. (2003): Effect of hypochlorite oxidation on the physicochemical properties of gladiolus starch; Journal of Pharm and allied Science. 1 (1) 28-35

Bandhari P. N., Singhal R. S. (2002): Studies on the optimization of preparation of succinate derivatives from corn and amaranth starches; Carbohydrate polymers $47: 277$ - 283

Builders P. E., Emeje M. And Kunle O.O (2001): Some physico - chemical properties of cyperus starch - A potential pharmaceutical excipient; Journal of Pharmaceutical and Allied Sciences 2 (1): 138 - 144

Charles A., Chang Y., Ko W., Sriroth K., Huang T. (2004): Some physical and chemical properties of starch isolates of cassava genotypes; Starch / Starke 56: 413 $-418$

Chowdary K. P. R. \& Enturi V. (2011): Preparation, characterization and evaluation of starch citrate- a new modified starch as a disintegrant in tablet formulations; International Journal of Pharm. Research and Development 12 (2) 9 - 17

Coursey D. G. And Rasper V. (1967): Properties of starches of some west African yams; J. Sci. Food Agric., 18: 240 - 248

Daramola B, and Osanyinlusi S. A. (2006): Investigation on modification of cassava starch using active components of ginger roots (Zingiber officinale Roscoe); African Journal of Biotechnology, 5: 917-920

Gebre - Mariam T., Schmidt P. C. (1996): Isolation and physicochemical properties of Endset starch; Starch / Starke 48 (6), 208 - 214.

Jay-lin J., Ames L. E. (1994): Anthology of Starch granule morphology by scanning electron microscopy; Starch / Starke 46 (4), 121 - 129. 
Loss P. J., Hood L. F. And Graham H. D. (1981): Isolation and characterization of starch from breadfruit; Cereal Chem. 58 (4): $282-286$

Nuwamanya E., Baguma Y., Emmambux N., Taylor J. and Rubaihayo P. (2010): Physicochemical and functional characteristics of cassava starch in Ugandan varieties and their progenies; Journal of Plant Breeding and Crop Science 2 (1) $001-011$

Omojola M. O., Akinkunmi Y. O., Olufunsho K. O., Egharevba H. O. and Martins E. O. (2010): Isolation and physico-chemical characterization of cola starch; African Journal of food, agriculture, nutrition and development. 10(7): $2884-2900$

Sadik N. (1991): Population growth and the food crisis; Food, Nutrition and Agriculture., 1: 3 - 6

Sofowora A. (1993): Medicinal plants and traditional medicine in Africa. Spectrum books, Ibadan Pp 150
Trubiano P. C. (1987): Succinates and substituted succinate derivatives of starch. In O. B. Wurzburg Modified starches: properties and uses. Pp 131 - 148. Boca Raton, Florida: CRC press

Viano J. , Massoti V., Gaydou E.M., Bourrreil P.J.L., Ghiglione, Giraud M. (1995): Compositional characteristics of 10 wild plant legumes from Mediterranean French pastures; J. Agric. Food Chem., 43: $680-683$

Vijayakumari K., Siddhuraju P., Janardhanan K., (1994): Nutritional assessment and chemical composition of the lesser known tree legume, Acacia leucophloea; Food Chem., 50: 2858

Weaver L. T. (1994): Feeding the weanling in the developing world - problems and solutions. Int. J. Food Sci. Nutr., 45: 127 - 134 